\title{
STUDY OF PRODUCTION OF REVERSE OSMOSIS DEMINERALIZED WATER FOR BOILERS
}

MICHELLE ZANIN ROVANI ${ }^{1}$

LIZANDRA KAMRADT SAVI ${ }^{1}$

LUCIANA IGARASHI MAFRA ${ }^{2}$ IVO MOTTIN DEMIATE ${ }^{3}$

\begin{abstract}
A comparison of the presence and absence of a softening system as a pretreatment of the water that is fed into the separation process by reverse osmosis membranes was performed. The following parameters of the reverse osmosis were evaluated: the $\mathrm{pH}$ of the feed water; the flow of the permeate; the pressure of the feed water in the membrane in the first and second stages; and the pressure of the reject, both in the absence and the presence of the softening system. The results indicated that the inclusion of a softening system as a pretreatment for feeding the reverse osmosis process prevented the premature deposition of silica, thereby increasing the useful life of the membranes.
\end{abstract}

KEYWORDS: REVERSE OSMOSIS; MEMBRANE; SOFTENER; DEMINERALIZED WATER.

1 Alunas do Programa de Pós-Graduação em Engenharia de Alimentos da Universidade Federal do Paraná, UFPR, Curitiba/PR (e-mail: mrovani@gmail.com).

2 Professora Doutora do Programa de Pós-Graduação em Engenharia de Alimentos da Universidade Federal do Paraná, UFPR, Curitiba/PR (e-mail: luciana.igarashi@gmail.com).

${ }^{3}$ Professor Doutor do Programa de Pós-Graduação em Ciência e Tecnologia de Alimentos da Universidade Estadual de Ponta Grossa, Ponta Grossa/PR (e-mail: demiate@gmail.com). 


\section{INTRODUCTION}

The quality of feed water in a high-pressure boiler is of great importance for its operation, since it avoids the boiler suffering from mechanical damage and also the need for water replacement [1].

Safe and corrosion-free boiler operation requires monitoring and adequate water treatment, with an emphasis on removing possible corrosive species [1, 2, 3]. Therefore, the control and monitoring of parameters such as total dissolved solids (TDS), boiler water conductivity, hardness index, alkalinity, content of carbon dioxide, oxygen and silica are recommended to avoid drag, deposit formation or the development of corrosive conditions [1, 2].

General processes around the world concerning water used in boilers (which must be demineralized), consist of distillation, ion exchange or reverse osmosis combined with ion exchange. These processes allow the removal of dissolved solids, which can be achieved by strict quality standards [4].

Reverse osmosis is a very promising technology for treating and reusing wastewater due to its unique properties, with no phase change or addition of chemicals, as well as its simplified operation [5].

The reverse osmosis process was applied to recover effluent from the palm oil industry and it was used as demineralized make-up water for boilers. The system was effective in reducing chemical oxygen demand, hardness and TDS [6].

This system, followed by ion exchange polishing, can be used to obtain mineral-free water. The reverse osmosis process and ion exchange were compared to obtain demineralized water for boilers and this application resulted in a reduction in operating costs and the introduction of a high level of automation in the water treatment process [1].

During their study of the application of reverse osmosis in sea water desalination for boiler feed, the characteristics of the water were analyzed before treatment. It contained concentrations of $124 \mathrm{mg} / \mathrm{L}$ hardness and $5 \mathrm{mg} / \mathrm{L}$ of silica [1]. In water collected to study hydrodynamic factors, it was obtained concentrations of $140 \mathrm{mg} / \mathrm{L}$ hardness and $8 \mathrm{mg} / \mathrm{L}$ of silica [7]. The effluent of secondary process of the steel industry was treated and it contained levels of $271 \mathrm{mg} / \mathrm{L}$ hardness and $664 \mathrm{mg} / \mathrm{L}$ of silica [8].

A serious limitation of commercial osmosis polyamide membranes is their sensitivity to attack by chlorine. The study of the sodium hypochlorite degradation of reverse osmosis membranes made of polyamide, showed that chlorination destroyed hydrogen bonds in the layers of the polyamide, causing a remarkable decrease in the transmembrane flow, especially at acid $\mathrm{pH}$ values [9].

Due to the high cost of the membranes used in reverse osmosis, they should be preserved. Silica is the biggest cause of fouling in water desalination and it is difficult to remove. Furthermore, the cleaning process of membranes contaminated by silica precipitation involves the risk of damaging it [10]. The solubility of silica is strongly affected by temperature, $\mathrm{pH}$ and the presence of salts [11].

The prevention of calcium carbonate precipitation in small reverse osmosis plants can be monitored by operating with a low recovery of permeate in order to minimize the concentration of bicarbonate in the concentrate stream. In larger plants, where higher permeate recovery values are used, preventative measures should be taken by adding acid to the feed stream (which allows the conversion of bicarbonate into carbonic acid and increases the solubility of calcium carbonate due to the low $\mathrm{pH}$ ), by the addition of a precipitation inhibitor, or by the prior removal of hardness, with the installation of a softening system [11].

Performing the Fujiwara test is a method to determine if the membrane is exposed to free chlorine or halogenic oxidizing agents [12].

The inclusion of a pretreatment of the feed water of the reverse osmosis membranes minimizes fouling, thus producing a smooth permeate flow, low levels of salts and a longer life for the membrane. In addition, the water should suit the SDI (silt density index) criterion to prevent clogging 
of the membranes [13].

This study aims to evaluate the operation of the reverse osmosis process in terms of the quality of the demineralized water used to feed high-pressure boilers.

\section{MATERIALS AND METHODS}

\subsection{WATER TREATMENT WITH REVERSE OSMOSIS}

Figure 1 shows the water treatment scheme before being subjected to reverse osmosis process. The water quality, in the absence and presence of a new stage of pretreatment, i.e. softening, was evaluated.

The reverse osmosis feed water was underground and was obtained from 11 wells. It was sent 20 hours a day to a storage tank, with a rest period of 4 hours for each well per day. The water was chlorinated with sodium hypochlorite in order to eliminate microbial contamination and then dechlorinated by the addition of sodium metabisulfite (in the absence of the softening system) or by activated carbon filtration (in the presence of the softening system) to prevent residual chlorine contact with the membrane, since the chlorine would violate the physical structure, and also to remove dirt and colloids.

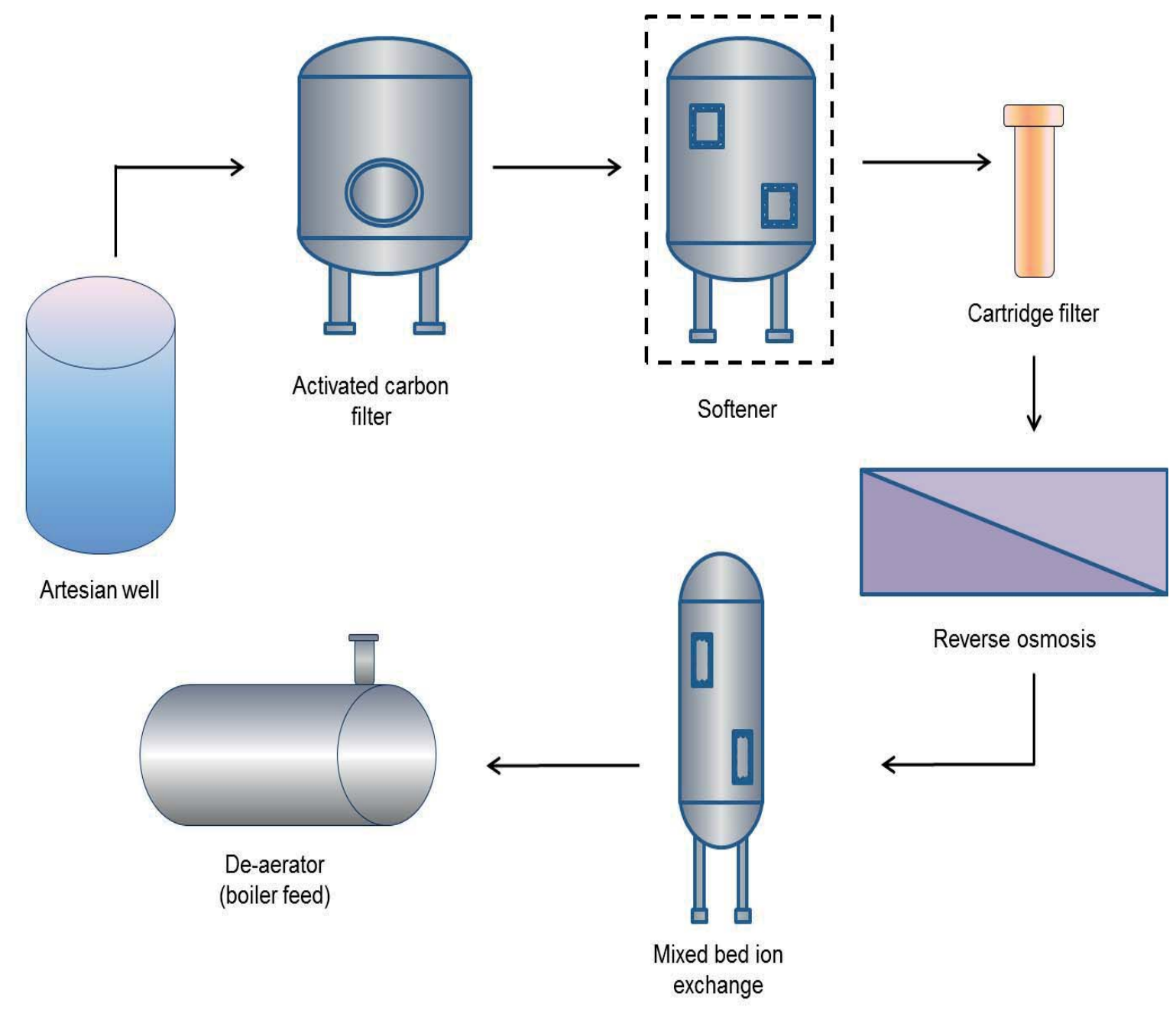

FIGURE 1: ORIGINAL WATER TREATMENT FLOW FROM ARTESIAN WELLS

Source: the authors. 
This water was subjected to a filtration cartridge process of 5 micrometer opening to ensure that no undesirable particles reached the membrane. Then sodium hydroxide was added to adjust the $\mathrm{pH}$, and sodium hexametaphosphate as an antifouling agent.

Then the permeate water from the reverse osmosis process was sent to the mixed bed ion exchange, where water polishing was performed to further reduce undesirable ion levels. Obtained ultra-pure water, it became a make-up water for high pressure boilers, sent to the deaerator (boiler feed), where oxygen dissolved in the water was removed, due to high temperature and addition of sodium sulfite.

Feed water samples of reverse osmosis and their corresponding streams were collected (permeate and reject) in the absence and presence of the softening system aiming to analytically characterize the flow.

\subsection{REVERSE OSMOSIS}

The permeation bank had a production capacity of $45 \mathrm{~m}^{3} / \mathrm{h}$ of permeate water. The permeation lines were arranged in the configuration 2:1, i.e. in the first arrangement there were six vessels and in the second one, three, as shown in Figure 2.

The reverse osmosis system was composed of 54 polyamide membranes, nine vessels with seven membranes each one, eight inch diameter, BW-30-400/34i spiral module model, with retention feature of $99 \%$ (Filmtec / Dow Chemical).

In this case, the water from the filter cartridge was pressurized by the high-pressure pump feeding the permeating vessels, comprising the first stage. Passing through the membranes, the flow was divided into two streams, one being demineralized water (permeate) and the other with a high concentration of salts (reject).

The first stage reject fed the permeating vessels comprising the second stage, generating the two streams. The purified water in the first and second stages was collected, forming the permeate stream. The reject from the second stage, with a high concentration of dissolved salts, was discarded from the system (Figure 2).

The permeate and feed streams were analyzed to evaluate the amount of solute (silica). The percentage of rejection or salt retention in the membrane was calculated according to Eq. 1.

$$
R_{(\%)}=\frac{\mathrm{C}_{\mathrm{f}}-\mathrm{c}_{\mathrm{p}}}{\mathrm{C}_{\mathrm{f}}} \cdot 100 R_{(\%)}=\frac{\mathrm{c}_{\mathrm{f}}-\mathrm{c}_{\mathrm{p}}}{\mathrm{C}_{\mathrm{f}}} \cdot 100 \quad(\text { Eq. 1) }
$$

Where $R_{(\%)}$ is the percentage of solute rejection by the membrane, $C_{f}$ is the concentration of solute in the feed, and $\mathrm{C}_{\mathrm{p}}$ is the solute concentration in the permeate.

The switch operated when the suction pressure in the high pressure pumps was low, avoiding cavitation and turning them off. Pressure gauges monitored the feed pressures of the first and second stages, and the reject. The differential pressure between the pressure gauges indicated the pressure drop of the $1 \mathrm{st}$ and 2 nd stages. When the pressure drop exceeded $15 \%$ of the parameter, a loss alarm indicated that the system needed to undergo chemical cleaning. Indicators signaled the concentrated flow and permeate from the reverse osmosis. The quality of permeate collected in the first stage was monitored by analytical methodology. 


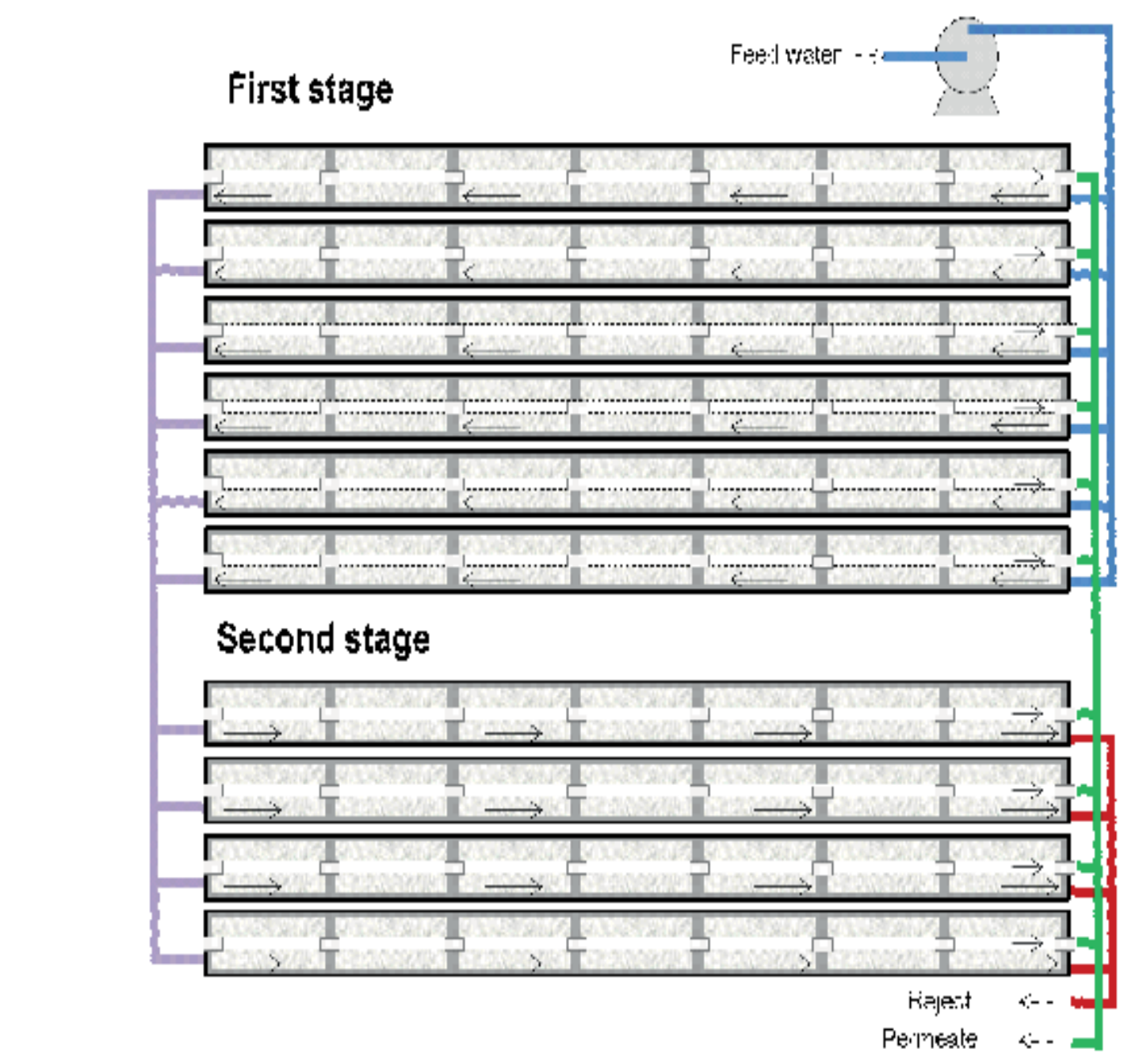

FIGURE 2 - REPRESENTATIVE SCHEME OF FEED WATER, PERMEATE AND REJECT FLOW IN THE PROCESS OF TWO STAGE REVERSE OSMOSIS. SOURCE: THE AUTHORS.

\subsection{ANALYTICAL METHODOLOGY}

The quality of the reverse osmosis feed water, in the absence and presence of a softening system, was monitored according to the $\mathrm{SDI}$ and $\mathrm{pH}$ analysis, regarding the evaluation probability of fouling by sediment [14]. Moreover, water features such as electrical conductivity, silica content, total hardness, SDT, turbidity, residual chlorine, iron and aluminum were monitored. All these analysis were based on The Standard Methods for the Examination of Water and Wastewater [15].

\section{RESULTS AND DISCUSSION}

\subsection{FEATURES OF REVERSE OSMOSIS FEED WATER PROCESS}

Characterization of the reverse osmosis feed water in the absence and presence of a softening system was performed. Table 1 shows the results for the concentration of soluble silica, hardness, SDT, residual chlorine, iron, aluminum, $\mathrm{pH}$, conductivity, turbidity and SDI analysis of the permeate and feed streams. 
TABLE 1 - CHARACTERIZATION OF FEED WATER IN THE REVERSE OSMOSIS PROCESS

\begin{tabular}{|c|c|c|c|c|}
\hline \multirow{2}{*}{ Parameters } & \multicolumn{2}{|c|}{ Absence of Softening } & \multicolumn{2}{|c|}{ Presence of Softening } \\
\hline & Feed & Permeate & Feed & Permeate \\
\hline Silica (mg/L) & $39.41 \pm 12.39$ & $1.04 \pm 0.13$ & $34.80 \pm 7.82$ & $0.67 \pm 0.02$ \\
\hline $\mathrm{pH}$ & $8.12 \pm 0.03$ & $6.28 \pm 0.05$ & $8.58 \pm 0.03$ & $6.72 \pm 0.021$ \\
\hline Alkalinity (mg/L) & $88.29 \pm 6.23$ & n.d. & n.d. & n.d. \\
\hline Conductivity $(\mu \mathrm{S} / \mathrm{cm})$ & $244.78 \pm 4.25$ & $9.33 \pm 3.69$ & $234.05 \pm 4.25$ & $7.74 \pm 4.22$ \\
\hline SDT (mg/L) & $183.59 \pm 2.03$ & $7.00 \pm 2.77$ & $175.54 \pm 2.03$ & $5.80 \pm 2.01$ \\
\hline SDI & $0.46 \pm 0.10$ & - & $0.61 \pm 0.10$ & - \\
\hline Turbidity (NTU) & 0.17 & - & 0.38 & - \\
\hline
\end{tabular}

n.d. - not detectable

The silica concentration in the reverse osmosis feed stream in the absence of the softening system had a small variation compared to the results obtained in the presence of the softening system, as shown in Table 1. This variation may have been due to the selection of the well that was in operation: it is absolutely necessary to change the well at intervals due to the rest of $4 \mathrm{~h}$ daily. There was a reduction in the silica concentration from feed to permeate stream of $97 \%$ and $98 \%$ in the absence and presence of softening, respectively. In the absence of the softening system the silica was complexed and it precipitated, leading to a higher concentration in the permeate flow. The higher the calcium concentration in solution, the higher the final amount of polymeric silicates (precipitates) and the lower the time for this saturation to be reached [16].

The flow is a measure of membrane performance and it decreases due to fouling. Fouling may also be reduced by chemical cleaning [3].

Calcium carbonate is easily controlled by the acidification of the feed using a softener or ion exchange to replace the calcium with sodium. No significant changes in the permeate $\mathrm{pH}$ values in the presence and absence of softener were verified [14].

The calcium and magnesium ions, which give hardness to water, were at a concentration of $88.29 \pm 6.23 \mathrm{mg} / \mathrm{l}$ before the installation of the softening system and after installation it was not possible to detect their concentration. The average concentration of hardness in the waste stream was $402.69 \pm 10.32 \mathrm{mg} / \mathrm{l}$ before the installation of the softening system, indicating that the softening process was able to remove the entire amount of hardness that was present, thus preventing the possibility of the precipitation of hardness on the membrane surface.

The conductivity before $(244.78 \pm 4.25 \mathrm{mg} / \mathrm{l}$ and $9.33 \pm 3.69 \mathrm{mg} / \mathrm{l})$ and after $(234.05 \pm 4.25$ $\mathrm{mg} / \mathrm{l}$ and $7.74 \pm 4.22 \mathrm{mg} / \mathrm{l}$ ) the installation of the softening system, in the feed and permeate flow, respectively, did not show a significant change because other ions are able to confer conductivity to the water, besides the ions of hardness. Likewise, the analysis of TDS showed the same behavior, as they were also measured by conductivity according of the methodology of the Standard Methods for the Examination of Water and Wastewater [15].

Concerning SDI, there was a small change in this value, it was $0.46 \pm 0.10$ in the absence of the softening system process and it was $0.61 \pm 0.01$ with the softening system process. Despite this variation, the SDI value remained below index 3 , the maximum suggested by the manufacturer 
of membranes and [14]. This same trend was observed for the NTU parameter: in the absence of the softening system the water turbidity in the feed stream was $0.17 \pm 0.00 \mathrm{NTU}$, and with the softening system it was $0.38 \pm 0.14$ NTU. Nevertheless, the value of the feed water turbidity remained below 1 NTU, the maximum value for acceptance for drinking water.

The residual chlorine values in the feed stream were kept equal to zero, while the aluminum and iron concentrations were $0.05 \mathrm{mg} / \mathrm{l}$ and $0.04 \mathrm{mg} / \mathrm{l}$ to $0.04 \mathrm{mg} / \mathrm{l}$, and $0.03 \mathrm{mg} / \mathrm{L}$, respectively.

The $\mathrm{pH}$ of the reverse osmosis feed water was altered to evaluate its effect on the concentration of hardness, SDT, conductivity and silica, in the absence and presence of the softening process (Figure 3).

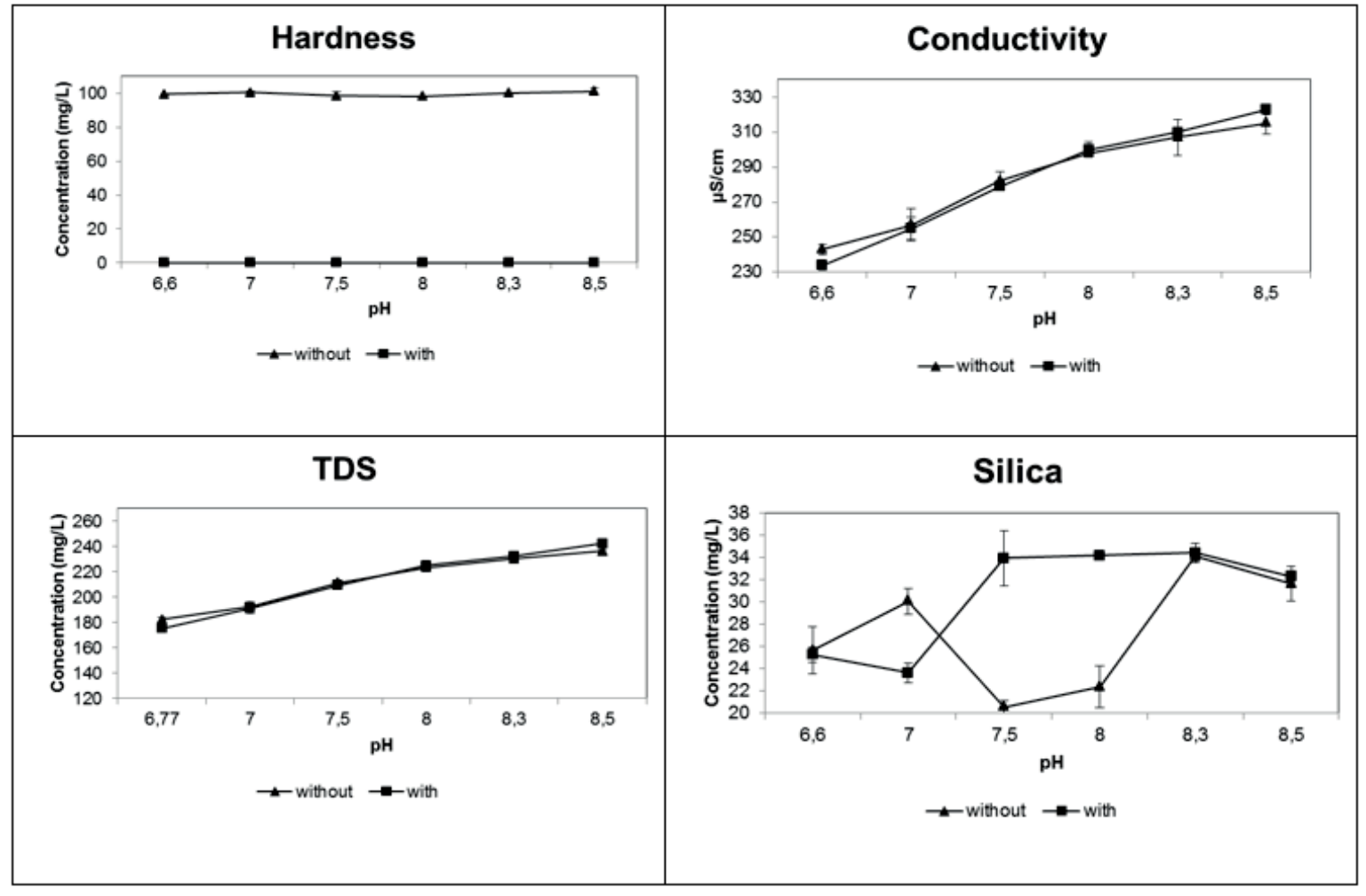

FIGURE 3 - EFFECT OF PH ON HARDNESS CONCENTRATION, CONDUCTIVITY, TDS AND SILICA IN THE ABSENCE AND PRESENCE OF SOFTENING SYSTEM.

Figure 3 shows that the concentration of TDS and conductivity increased with the increasing $\mathrm{pH}$ of the feed water in the absence and presence of the softening system. In more alkaline $\mathrm{pH}$, the repulsion between the ions increases, improving conductivity to water. The concentration of hardness was not affected by pH changes in the absence of the softener. In its presence, the concentration of hardness was eliminated.

The silica concentration was sensitive to $\mathrm{pH}$ variation, and in different ways in the presence and absence of softener. In the absence of softener, or in the presence of hardness, the silica concentration was lower (ranging from $20.38 \pm 0.5 \mathrm{mg} / \mathrm{l}$ to $22 \pm 0.3 \mathrm{mg} / \mathrm{l}$ ) between $\mathrm{pH}$ values from 7.5 to 8 , whereas at $\mathrm{pH} 8.3$ to reach a higher silica concentration, the amount of $34.14 \pm 0.90 \mathrm{mg} / \mathrm{l}$.

Knowing that the same sample was used at different adjusted $\mathrm{pH}$ values, it can be concluded that when the analysis of soluble silica resulted in a lower concentration that does not mean that silica was not present, but that it was not soluble, so the analysis was not able to determine it. Thus, at $\mathrm{pH} 8.3$ and 8.5 , silica is more soluble, so those values would be the best to work with because of the probability that the occurrence of precipitation on the membrane would be lower. At a pH below 8 , silicic acid $\left(\mathrm{H}_{4} \mathrm{SiO}_{4}\right)$ dissociates to silicate anion $\left(\mathrm{SiO}_{3}{ }^{-2}\right)$, increasing the solubility of silica. However, in the presence of multivalent cations in high concentrations, insoluble silicates are formed, which deposit on the membrane surface [11]. 
In the absence of the softening system, the lowest concentration of silica $(23.64 \pm 0.8 \mathrm{mg} / \mathrm{l})$ at $\mathrm{pH} 7$ was found. These values were not as low as when in the presence of hardness because, when there is the presence of a salt the charge repulsion decreases, and there may be aggregation and gel formation on the membrane surface [16].

\subsection{EVALUATION OF MEMBRANE PERFORMANCE}

\subsubsection{Recovery}

Figure 4 shows the recovery rate as a function of feed pressure. Except in the process of the starting period (up to $9.42 \mathrm{kgf} / \mathrm{cm}^{2}$ ) the system maintained $75 \%$ recovery with $60 \mathrm{~m}^{3} / \mathrm{h}$ feed flow and permeate flow of $45 \mathrm{~m}^{3} / \mathrm{h}$. This value was expected, as it was predicted by the membrane manufacturer and also in a study by [17].

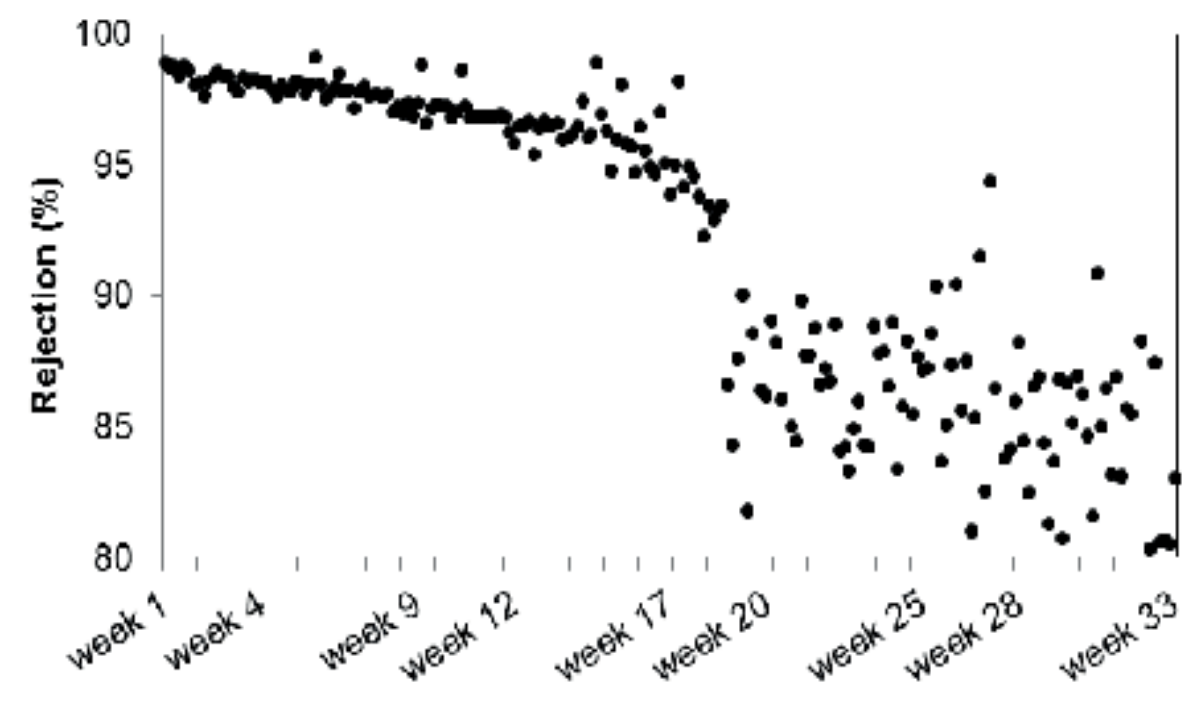

FIGURE 4 - RECOVERY RATE IN FEED PRESSURE FUNCTION.

\subsubsection{Rejection}

Figure 5 shows the percentage of retention of the membrane to the passage of salts. At the beginning of the process in the plant (week 1), the membranes had a rejection of $97 \%$. It was observed that the rejection decreased gradually over time and in the 17th week there was a marked decrease in rejection, reaching the minimum of $80 \%$. This event coincided with the chemical cleaning of the membranes. Chemical cleaning is aggressive; it can cause oxidation of the electrical charges on the membrane surface and damage their selective capacity $[5,10]$.

After installing the softening system, rejection began to have more constant values, with an average of $98 \%$ (Figure 6). It was observed that after two months of operation of the reverse osmosis with the softener as pretreatment, the rejection was not below $97 \%$. 


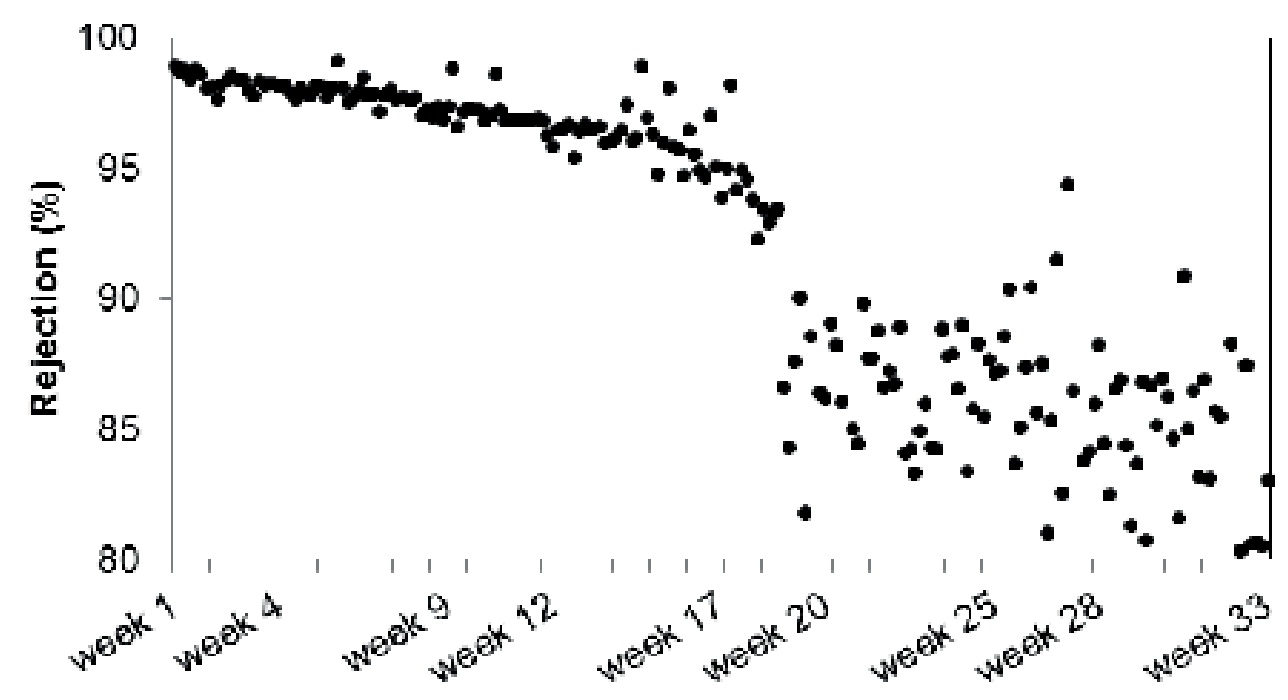

FIGURE 5 - PERCENTAGE OF REJECTION OF SOFTENING IN MEMBRANE SYSTEM FAILURE.

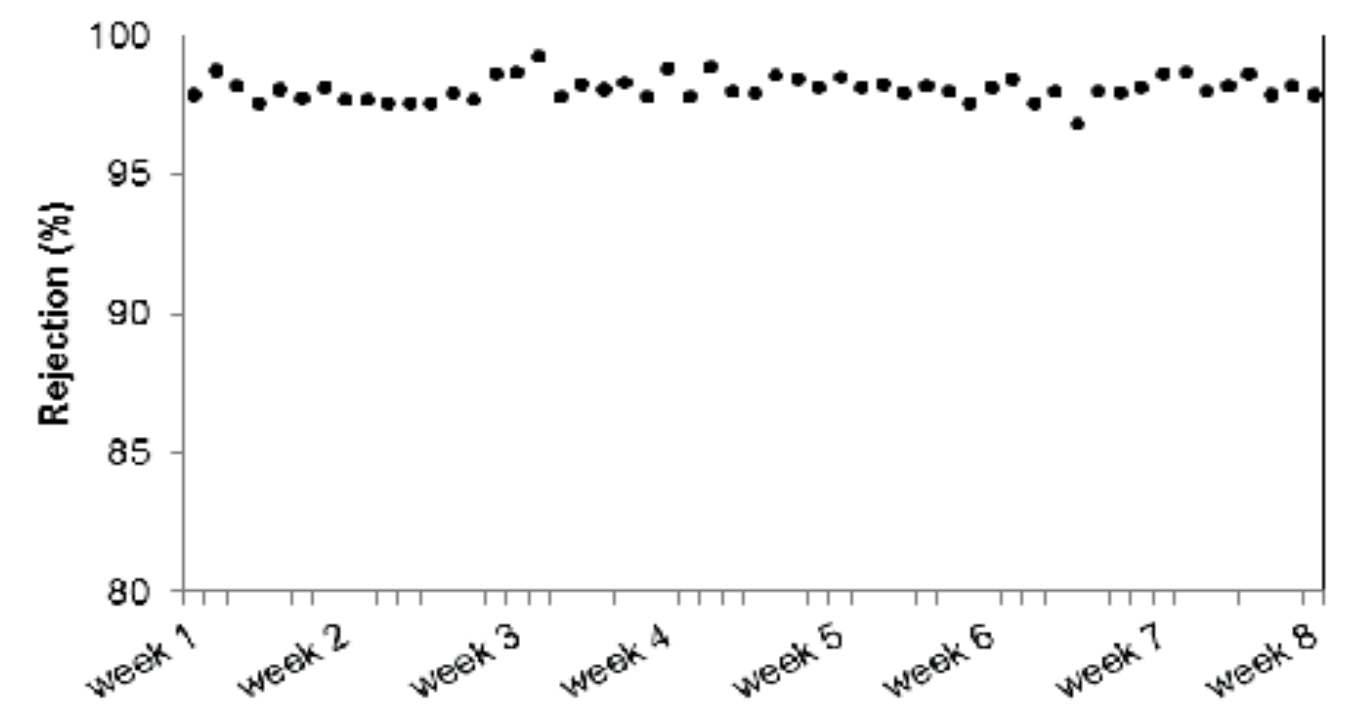

FIGURE 6 - PERCENTAGE OF REJECTION OF MEMBRANE IN THE PERIOD SUBSEQUENT TO THE INSTALLATION OF SOFTENING SYSTEM. 


\subsubsection{Water permeability and Fujiwara test}

The transmembrane permeability or cell test analysis was performed in the absence of the softening installation process and was carried out after the chemical cleaning. It was possible to confirm increases in the passage of water and salts through the membrane, which were in the order of $135 \%$ and $225 \%$ of normal flow, respectively (Table 2 ).

Chlorination destroys hydrogen bonds in the layers of polyamide, causing a notable decline in the transmembrane flow [9]. For this reason, the Fujiwara test was performed to verify if the membrane with a polyamide surface layer had been exposed to any ion oxidative halogen, such as chlorine, bromine or iodine. However, this test was negative for halogens in the structure that was used as a membrane sample.

TABLE 2: PERMEABILITY TEST RESULTS FOR TRANSMEMBRANE PERMEATE AND SALTS FLOW.

\begin{tabular}{lcc}
\hline Parameters & $\begin{array}{c}\text { Permeate flow } \\
\text { (cm/s atm) }\end{array}$ & $\begin{array}{c}\text { Salts Flow } \\
\text { (cm/s) }\end{array}$ \\
\hline Manufacturer specification & $(1.30-1.75) \cdot 10^{4}$ & $(1.18-1.59) \cdot 10^{5}$ \\
Cell test & $2.36 \cdot 10^{4}$ & $3.58 \cdot 10^{5}$ \\
\hline
\end{tabular}

Figure 7 demonstrates that there was no clogged material, or organic or visible bacterial fouling on the membrane surface. The high level of pass salts was not caused by oxidation by halogens, which can be associated with non-oxidizing halogens, for example, peroxides or aggressive hydrolysis $\mathrm{pH}$ and chemical cleaning with acid solutions and soda. Changes in feed stream $\mathrm{pH}$ may alter the nature of the surface charge of the membrane, which may consequently affect the membrane performance [18].

\subsubsection{Conductivity}

In conventional processes for treating water to feed reverse osmosis the permeate has low conductivity values at the beginning of the operation and it gradually increases, indicating the presence of ions at high concentrations. At the same time, it was observed that regarding rejection, which gradually decreased, there was a sudden drop between the 17th and 20th week (Figure 8).

Having deployed the softener, it was observed that the conductivity remained at constant values, as occurred with the rejection (Figure 9), indicating that the softener removed the ions that give hardness to the solution and helped the increase in the passage of ions through the membrane. 

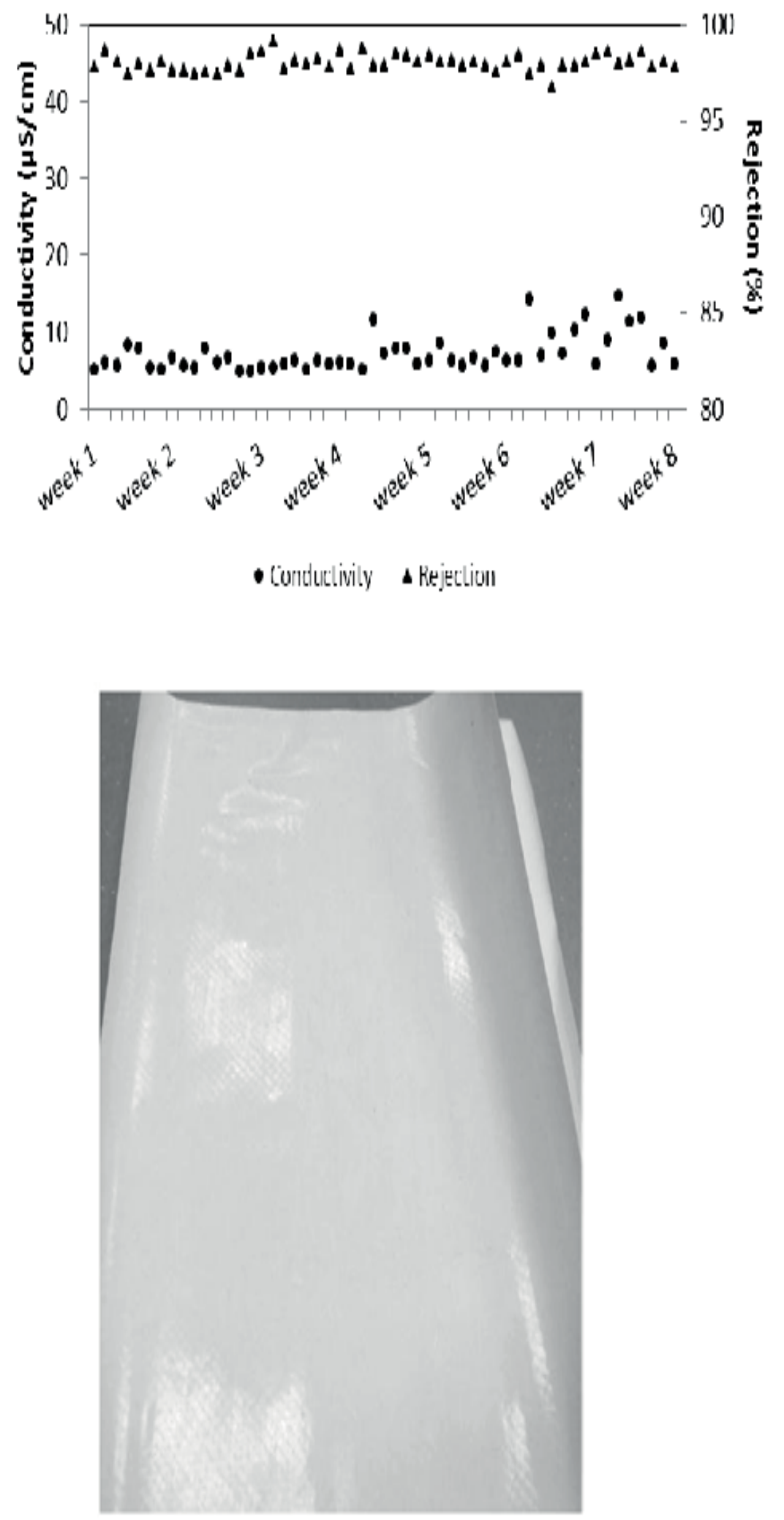

FIGURE 7 - IMAGE OF MEMBRANE SUBMITTED TO PERFORMANCE ANALYSIS. 


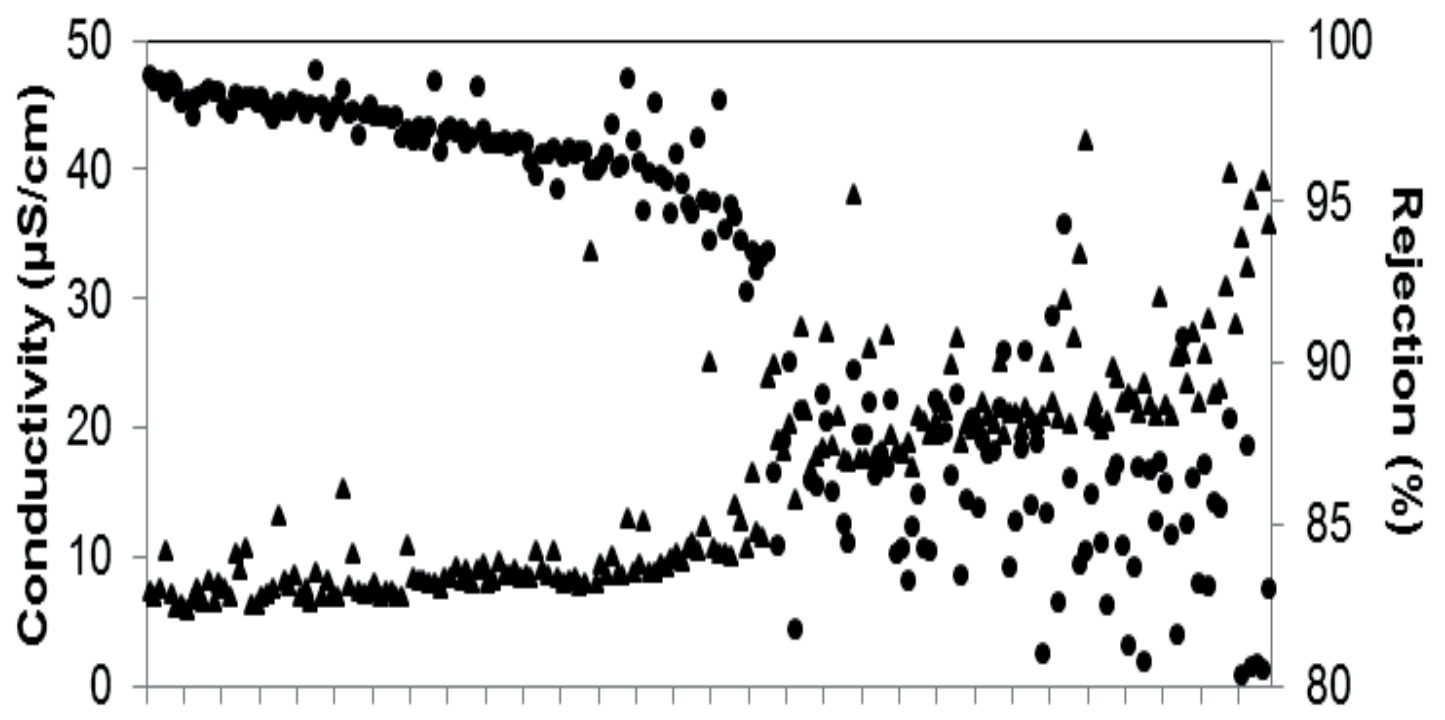

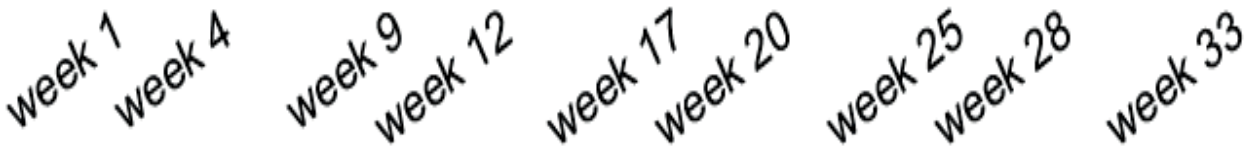

$\Delta$ Conductivity $\bullet$ Rejection

FIGURE 8 - EFFECT OF MEMBRANE CONDUCTIVITY IN THE PERIOD PRIOR TO THE INSTALLATION OF THE SOFTENING SYSTEM.

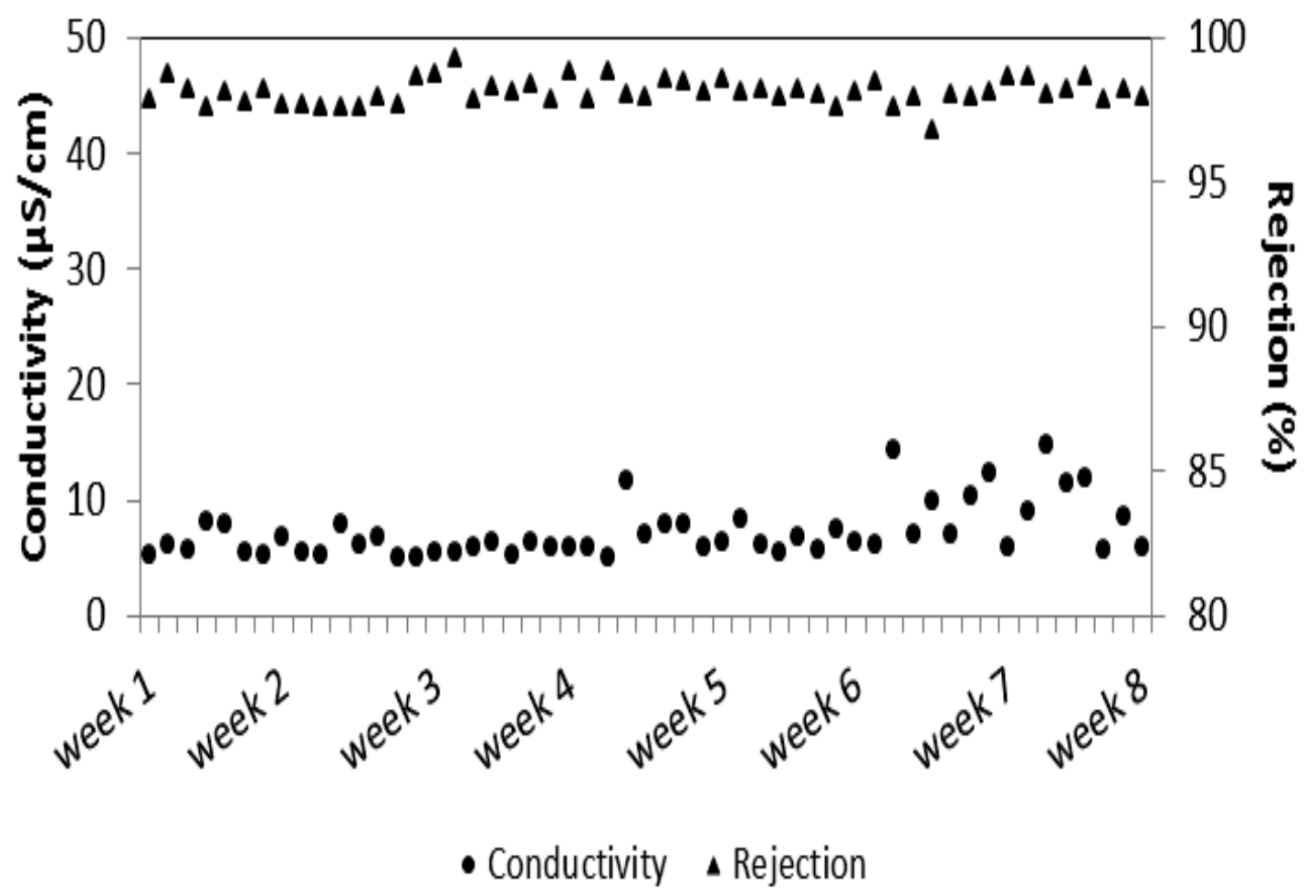

FIGURE 9 - EFFECT OF MEMBRANE CONDUCTIVITY REJECTION IN THE PERIOD SUBSEQUENT TO THE INSTALLATION OF THE SOFTENING SYSTEM. 


\subsubsection{Evaluation of feed pressures}

In industrial process the feed and waste flows are kept constant and therefore there is little variation in the permeate flow, which absorbs the variation in the process of recovery. Typically, studies on this subject have showed a decrease in permeate flow, as there is an increase in fouling of the membrane $[7,19]$. In this study, the change should have been noticed by an increase in feed pressure, when the pressure data from the waste, 1 st and 2 nd stages, the permeate flow and the $\mathrm{pH}$ of the feed of the dynamic process were collected.

The pressure of reverse osmosis system varies as a function of transmembrane flux. Because the test system was controlled by permeate flow, as the resistance increased by passing water through the membrane, feed pressure also increased, and as a result, there were increased system pressures. Before the implementation of the softening system (Figure 10), it was observed that the feed pressure was lower, starting at $8.46 \pm 1.30 \mathrm{kgf} / \mathrm{cm}^{2}$ in the first week and reaching a value of $7.68 \pm 0.02 \mathrm{kgf} / \mathrm{cm}^{2}$ at 12 weeks of operation. Over a period of 12 weeks, there was no increase in the feed pressure. There was only a small increase in feed pressure from the seventh to the eighth week $\left(8.74 \pm 0.01 \mathrm{kgf} / \mathrm{cm}^{2}\right.$ to $\left.9.04 \pm 0.06 \mathrm{kgf} / \mathrm{cm}^{2}\right)$. Then chemical cleaning was applied to the first stage membranes, which explains the sudden decrease during the ninth week only in the feed pressure.

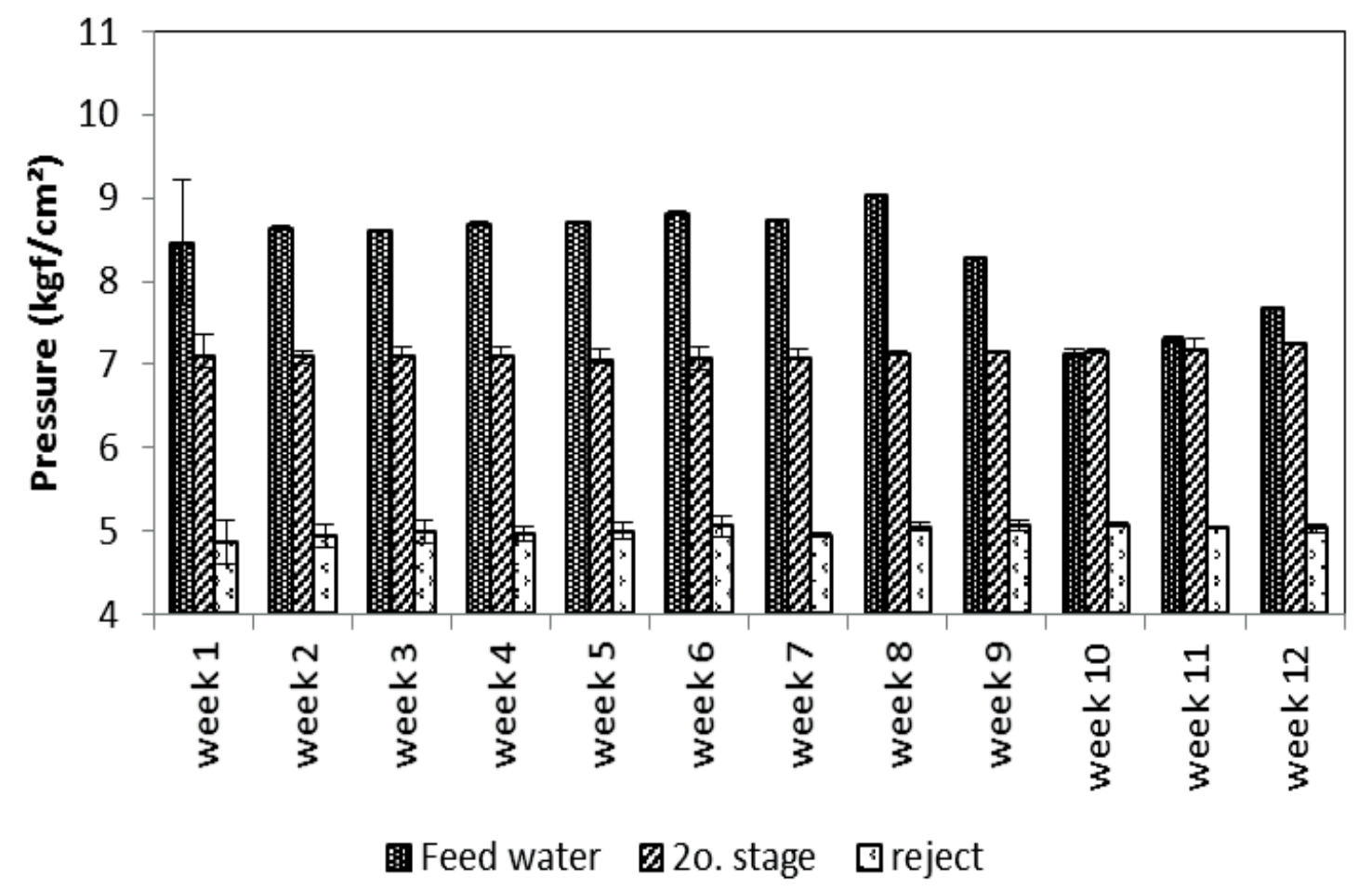

\section{FIGURE 10 - PRESSURES OF FEED WATER, THE SECOND STAGE AND REJECT BEFORE THE IMPLEMENTATION OF THE SOFTENING SYSTEM.}

Figure 11 shows that the pressures ranged from $9.49 \pm 0.76 \mathrm{kgf} / \mathrm{cm}^{2}$ in the first week to 10.00 $\pm 0.01 \mathrm{kgf} / \mathrm{cm}^{2}$, reaching a maximum value of $10.22 \pm 0.04 \mathrm{kgf} / \mathrm{cm}^{2}$ for the feed stream in the eleventh week of operation. From the second week, the feed pressure, which was already high, remained constant. The reverse osmosis system showed the lowest pressures in the absence of the softening system. However, it was noticed that they did not remain constant when compared to the pressures in the new system. Because changing membranes generates high manufacturing costs, it is important that they are used for the time recommended by the manufacturer. With a more constant system, the chances are higher that this period will be reached. Many manufacturers provide membranes 
with 1-2 years warranty, depending on usage. The expected life of the membranes installed in welldesigned industrial plants and with a good pretreatment system should be at least three years. There are rare cases of five years or longer [14].

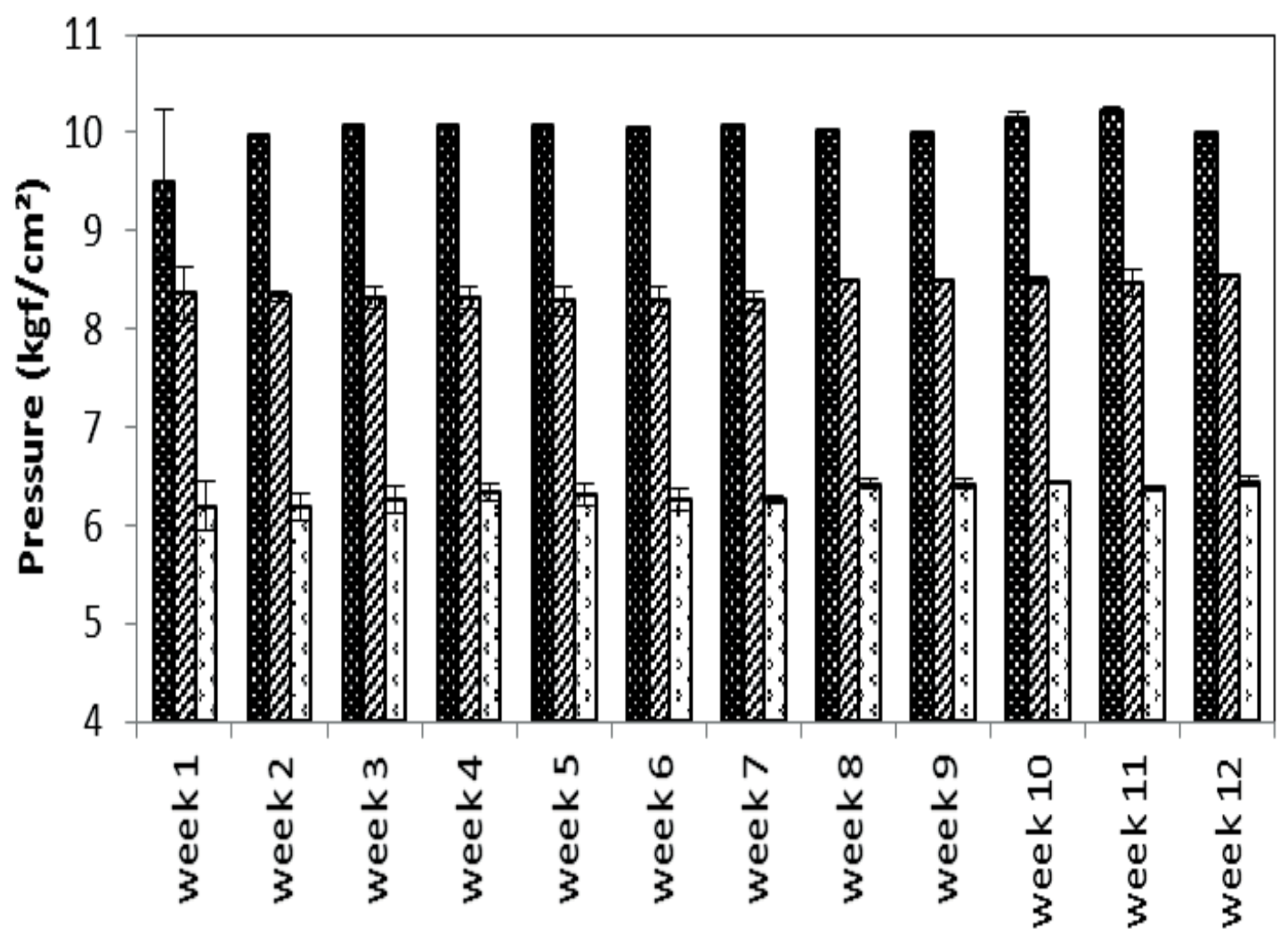

Feed water $\mathbf{2 0}$. stage $\mathbf{B}$ Reject

\section{FIGURE 11 - PRESSURES OF FEED WATER, SECOND STAGE AND REJECT AFTER THE IMPLEMENTATION OF THE SOFTENING SYSTEM.}

\section{CONCLUSION}

The water that was collected for reverse osmosis treatment contained high concentrations of hardness and silica, and there was a variation according to the changing of the well. The membrane decreased the silica concentration from $97 \%$ to $98 \%$ in the presence of softening system, reaching an average permeate value of $0.67 \pm 0.02 \mathrm{mg} / \mathrm{l}$. Hardness was eliminated by installing the softener, thereby contributing to the reduction of silica in the permeate, and as a result, sending purer and higher quality water to the steam generation system, allowing for a greater concentration cycle in the high-pressure boiler.

The SDI values remained below 3 , which was the necessary value for a good performance by the membrane, while the turbidity value doubled after the implantation of the softening system. However, it remained below 1 NTU, which is the maximum value for acceptable drinking water.

Evaluating the influence of $\mathrm{pH}$ on the salts concentration, it was observed that hardness, conductivity and TDS in the feed flow did not vary significantly, which was different from silica, which, when in the presence of hardness, had the lowest concentration at pH 7.5 and 8 . In the absence of hardness, low silica concentration was reached at $\mathrm{pH} 7$.

Conductivity had an influence on the retention of the membrane. When there was no 
pretreatment for the removal of hardness, conductivity increased gradually, while salt rejection decreased. The increase in conductivity and decrease in rejection was sudden because of the chemical cleaning. With no hardness in the feed flow until the eighth week, there was no variation in these characteristics.

After reaching the working pressure of the system, the recovery was maintained at $75 \%$.

Despite the fact that the reverse osmosis system had lower pressures before the installation of the softening system, it was observed that they did not remain constant when compared to the pressure after installing the new system.

The incorporation of a softening system, as pretreatment for feeding reverse osmosis, provided with a protective membrane can prevent the premature deposition of silica.

\section{RESUMO}

\section{ESTUDO DA OSMOSE INVERSA NA PRODUÇÃO DE ÁGUA DESMINERALIZADA PARA CALDEIRAS}

Neste trabalho foi realizado um estudo de comparação da ausência e presença de um sistema de abrandamento como pré-tratamento da água que é alimentada no processo de separação por membranas de osmose inversa. Foram avaliados alguns parâmetros de operação da osmose inversa como a pressão na entrada dos $1^{\circ} \mathrm{e} 2^{\circ}$ estágios da alimentação da membrana, pressão do rejeito, fluxo do permeado e pH da água de alimentação, na ausência e presença do sistema de abrandamento da água. Os resultados obtidos indicaram que a inserção do sistema de abrandamento como pré-tratamento para alimentação do processo de osmose inversa evitou a deposição precoce de sílica, aumentando com isso o tempo de vida útil das membranas.

PALAVRAS-CHAVE: OSMOSE INVERSA; MEMBRANA; ABRANDADOR; ÁGUA DESMINERALIZADA.

\section{REFERENCES}

1 Čuda, P.; Pospíšil, P.; Tenglerová, J.; Reverse osmosis in water treatment for boilers. Desalination, v. 198, p. 41-46 (2006).

2 Frayne, C.; Boiler water treatment: principles and practice. Chemical Publishing Inc. Co. (2002).

3 Chattoraj, I.; Das, S. K.; B. Ravikumar, B.; D. K. Bhattacharya, D. K.; Corrosive degradation and failure of vertical furnace wall tubes of a boiler. Engineering Failure Analysis, v. 4, p. 279-286 (1997).

4 Oosterom, H. A.; Koenhen, D. M.; Bos, M.; Production of demineralized water out of rainwater: environmentally saving, energy efficient and cost effective. Desalination, v. 131, p. 345-352 (2000).

5 Madaeni, S.S.; Samieirad, S.; Chemical cleaning of reverse osmosis membrane fouled bay wastewater. Desalination, v.257, p. 80-86 (2010).

6 Koo, C.H.; Mohammad, A.W.; Sujá, F.; Recycling of oleochemical wastewater for boiler feed water using reverse osmoses membranes - A case study. Desalination, v. 271, p. 178-186 (2011).

7 Mohammadi, T.; Moghadam, M. K.; Madaeni, S. S.; Hydrodynamic factors effecting flux and fouling during reverse osmosis of seawater. Desalination, v. 151, p. 239-245 (2002).

8 Lee, J.W.; Kwon, T.O.; Moon, S.; Performance of polyamide reverse osmosis membranes for steel wastewater reuse. Desalination, v. 177, p. 69-82 (2009).

9 Kang, G.; Gao, C.; Chen, W.; Jie, X., Cao, Y.; Yuan, Q.; Sudy on hypochlorite degradation of aromatic poliamid reverse osmosis membrane. Journal of Membrane Science, v. 300, p. 165-171 (2007).

10 Sheikholeislam, R.; Al-Mutaz, I.S.; Koo, T.; Young, A.; Pretreatment and the effect of cations and anions on prevention of silica fouling. Desalination, v. 139, p. 83-95 (2001). 
11 Byrne, W.; Reverse Osmosis - A practical guide for industrial users, 2nd edition, Tall Oaks Publishing (2002).

12 Kolthoff, I. M.; Treatise on Analytical Chemistry. Wiley Interscience, v. 2, p. 125 (1971).

13 Dudley, L. Y.; Darton, E.G.; Pretreatment procedures to control biogrowth and scale formation in membrane systems. Desalination, v. 110, p. 11-20 (1997).

14 Baker, R.W; Membrane technology and applications, 2nd edition, Wiley Publisher (2004).

15 American Public Health Association (APHA); Standard methods for the examination of water and wastewater. 20th edition. Washington (1998).

16 Braun, G.; Hater, W.; Kolk, C.Z.; Dupoiron, C.; Harrer, T.; Gotz, T.; Investigations of silica scaling on reverse osmosis membranes. Desalination, v. 250, p. 982-984 (2010)

17 González, A.P.; Urtiaga, A.M.; Ibánez, R.; Ortiz, I.; State of the art and review on the treatment Technologies of water reverse osmosis concentrates. Water Research, v. 46, p. 267-283 (2012).

18 Hoang, T.; Stevens, G.; Kentish, S.; The effect of feed pH on the performance of a reverse osmosis membrane. Desalination, v. 261, p. 99-103 (2010).

19 Gurak, P.D.; Cabral, L.M.; Rocha-Leão, M.H.M.; Matta, V.M.; Freitas, S.P.; Quality evaluation of grape juice concentrated by reverse osmosis. Journal of Food Engineering, v. 96, p. 421-426 (2010). 